\title{
経尿道的前立腺切除術後の疼痛と不快感に対する 竜胆瀉肝湯の有效性に関する臨床的検討
}

\author{
古屋 聖児 $\mathrm{a}$ 高橋謙之祐 ${ }^{\mathrm{b}}$ \\ a 古屋病院，北海道， $\overline{\mathrm{T}}$ 090-0065 北見市寿町 2 丁目 \\ b 為山堂医院, 北海道, $\overline{\mathrm{T}} 090-0040$ 北見市大通西 4丁目
}

\section{Clinical Investigation of the Efficacy of Ryutan-shakan-to in the Treatment of Postoperative Pain and Discomfort Following Transurethral Resection of the Prostate}

\author{
Seiji FURUYA $^{\mathrm{a}} \quad$ Kennosuke TAKAHASHI $^{\mathrm{b}}$
}

a Furuya Hospital, 2-chome Kotobuki-cho, Kitamishi 090-0065, Hokkaido, Japan

b Isando Hospital, 4-chome Odori-Nishi, Kitamishi 090-0040, Hokkaido, Japan

\begin{abstract}
We studied patients following transurethral resection of the prostate (TURP) in order to assess the efficacy of Ryutan-shakan-to in the treatment of post-TURPpain and discomfort (PTPD). The study utilized the Japanese-language edition (draft) of the National Institutes of Health Chronic Prostatitis Symptom Index (NIH -CPSI). Our subjects were 15 patients of age 57 to 77 (mean age 69.8 years) who had undergone TURP 0.8 to 10 years (mean 3.4 years) previously. The patients filled out the Japanese version (draft) of NIH-CPSI before starting treatment with Ryutan-shakan-to (7.5 g/day) and every 2 weeks after the start of treatment. The duration of treatment with Ryutan-shakan-to was 2 to 16 weeks (mean 6.4 weeks). Results showed that Ryutanshakan-to was effective in treating PTPD in 11 cases (73\%) and ineffective in 4 cases (27\%). Scores (mean \pm standard deviation) for pain severity, pain frequency, and quality of life (QOL) were significantly better at the end of treatment than at baseline, with values decreasing from $5.8 \pm 1.5$ to $2.6 \pm 1.9$ for severity of pain $(\mathrm{p}=$ 0.0014 ), from $3.4 \pm 0.9$ to $2.0 \pm 1.5$ for frequency of pain ( $\mathrm{p}=0.0096)$, and from $4.5 \pm 0.7$ to $2.6 \pm 1.4$ for QOL ( $p$ $=0.0033$ ), respectively. These results indicate that Ryutan-shakan-to offers a useful treatment option for patients with PTPD.
\end{abstract}

Key words : transurethral resection of the prostate, postoperative pain, Ryutan-shakan-to

要旨

経尿道的前立腺切除(TURP)術後の疼痛 · 不快感 (Post-TURP pain/discomfort, PTPD) に対する竜胆瀉肝 湯の有効性を, The National Institutes of Health Chronic Prostatitis Symptom Index (NIH-CPSI) 日本語 版(案)を用いて検討した。対象症例は15例で，年令は57〜77歳 (平均69.8歳)，TURP 術後経過年数は0.8〜10年 (平 均3.4年) であった。竜胆瀉肝湯（7.5g/日）の投与前と投与後 2 週毎，患者に NIH-CPSI 日本語版(案)に記入して もらった。竜胆瀉肝湯の投与終了までの期間は，2１6週（平均6.4週）であった。PTPDに対する竜胆瀉肝湯の 効果は, 有効症例が11例 (73\%), 無効症例が 4 例（27\%）であった。竜胆瀉肝湯投与前と投与終了時の疼痛の重症

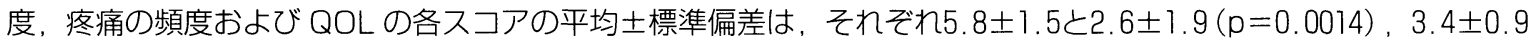

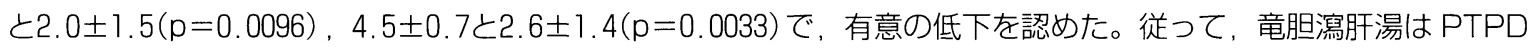
の治療薬の選択肢の一つとして有用であると考える。

キーワード : 経尿道的前立腺切除, 術後疼痛, 竜胆瀉肝湯

\section{緒言}

経尿道的前立腺切除術 (TURP) 後, 数力月または 数年後に, 下腹部, 尿道・陰茎, 陰囊および会陰部 に疼痛 · 不快感 (Post-TURP pain/discomfort, PTPD)
を訴える症例が稀に存在する。その病態生理は不明 であるため，現在まだ治療方針が確立されていない。 そのため, 日常臨床の場で PTPDの治療に泌尿器科 医が難渋することがある。我々は以前，消炎鎮痛薬， 
抗菌薬，植物製薬（セルニチンポーレンエキス）な どが無効であったが，尿路不定愁訴の治療に用いら れる竜胆瀉肝湯を投与したところ，劇的に効いた PTPD 症例を数例経験した。この経験に基づき，今 回, PTPD に対する竜胆瀉肝湯の有効性を, The National Institutes of Health Chronic Prostatitis Symptom Index (NIH-CPSI $)^{1)}$ の日本語版 (案) ${ }^{2)}$ 用いて検討 した。NIH-CPSI は, 慢性前立腺炎の症状や患者の 日常生活の影響を正確に判定するために作られた指 標で, 治療の経過の評価や治療法の効果判定に用い られる1”。われわれは，NIH-CPSI 日本語版（案）の 中の疼痛領域 (pain domains) スコアと QOL スコア を用いて，竜胆瀉肝湯の有効性を客観的に評価する ことを試みた。また， Drug challenge test $(\mathrm{DCT})^{3)}$ 行い, PTPDの発症機序を検討したので報告する。

\section{症例と方法}

1. 対象症例
2000年 12 月から 2002 年 6 月の期間，下腹部，尿道， 陰茎, 陰囊および会除部などの疼痛や不快感を訴え て当院外来を受診したTURP 術後患者を全例対象 とした。対象症例は15例で, 年令は57〜77歳（平均 69.8歳), TURP術後の経過年数は, $0.8 \sim 10$ 年 (平 均3.4年）であった。この内11例は，今迄にも同様 の症状をくり返す既往歴のある症例であった。その 場合, 抗菌薬, 抗炎症薬, 植物製薬 (セルニチンポー レンエキス) や抗コリン薬などの投与による治療を 受けたが，有効な改善が認められなかった。また， その内 2 例は仙骨硬膜外ブロックを受けた既往があ るが, その効果は少なかった。全例, 一般尿検査で は膿尿, 血尿, 細菌尿を認めなかった。排尿困難を 訴えた症例はいなかったが，頻尿は 2 例に認められ た。尿流検査では, 最大尿流率11２7（平均18.3） $\mathrm{ml} / \mathrm{sec}$, 残尿量は 0 35（平均15.5） $\mathrm{ml}$ であった。

2 . 竜胆瀉肝湯投与

表 1 NIH-CPSI 日本語版（案）の抜粋

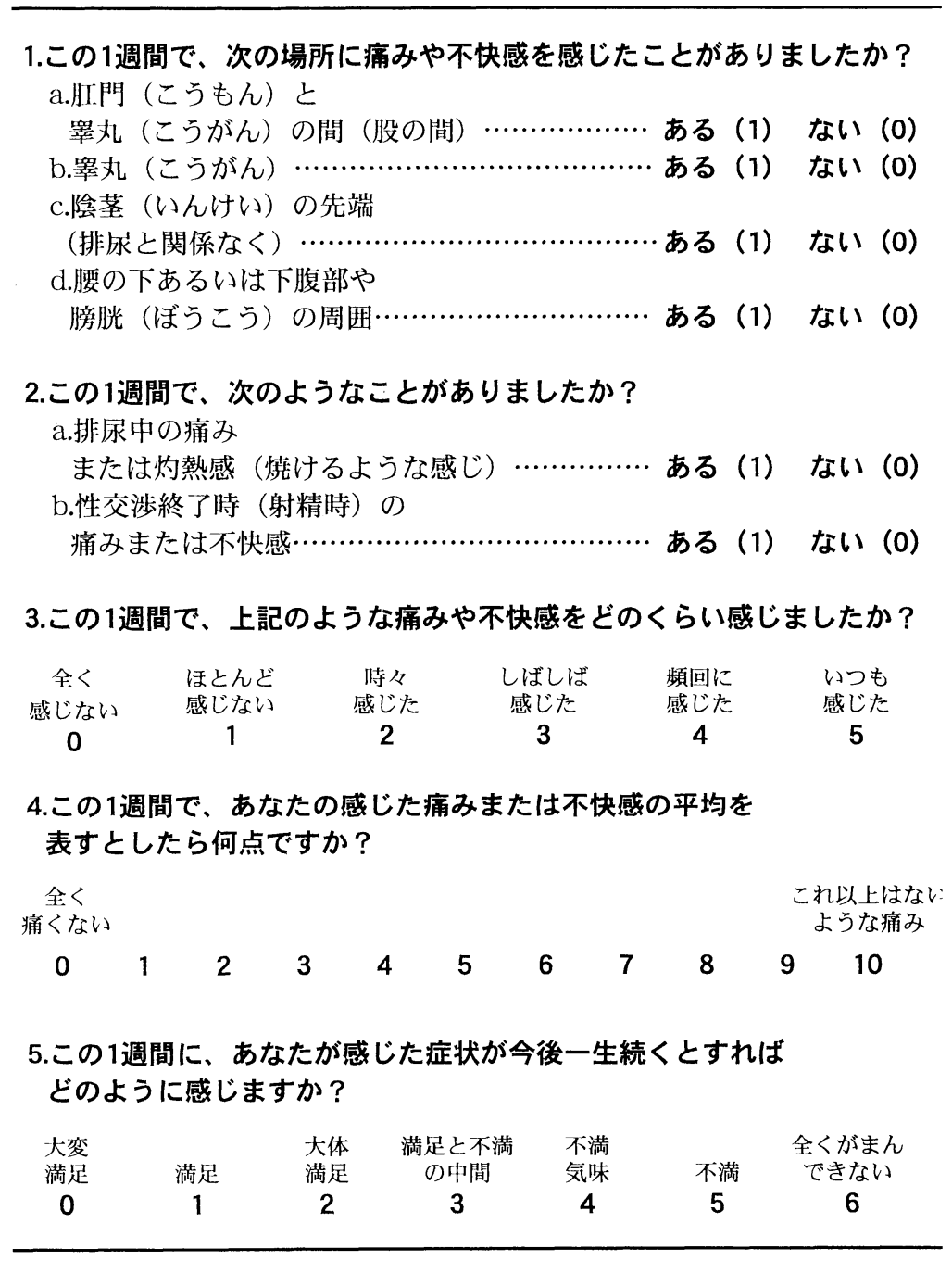


患者の虚，実を考慮せず，全例に竜胆瀉肝湯 (7.5 $\mathrm{g} /$ 日）を投与した。投与前，および投与後 2 週毎に， 患者にNIH-CPSI 日本語版（案）に記入してもらっ た。NIH-CPSI 日本語版（案）は9 項目から成って いるが，今回我々が用いたのはこの内の 5 項目であ る（表 1 ）。すなわち，疼痛の部位（項目 1 と 2 ）， 疼痛の頻度（項目 3） と疼痛の重症度（項目 4）の 疼痛領域計 4 項目と患者の満足度（QOL，項目 5 ） の 1 項目である。NIH-CPSI での疼痛の重症度評価 法は，一般に用いられているVisual analogue scale （VAS）と同様に，10点法により，0点を「全く痛 くない」，10点を「これ以上はないような痛み」と して，その時感じている痛みの程度を患者が主観的 に点数で評価するものである。

治療効果の判定は, 本人の自覚症状に基づいて行 なった。すなわち, 症状が改善したためか, または 不変・悪化したため, 患者が竜胆瀉肝湯の投与中止 を希望した時点を投与終了時とし, 前者の症例を「有 効群」, 後者の症例を「無効群」と分類した。また, 竜胆瀉肝湯投与前と投与終了後の疼痛の重症度 $(0$ ～10), 疼痛の頻度 $(0 \sim 5)$ および QOL $(0 \sim 6)$ のスコアおよび各指標の改善度を統計学的に検定し た。投与終了迄の期間は, 最短 2 週, 最長 16 週で,
平均6.4週であった。 3 指標の改善度は, 表 2 に示 す基準により，「著効」，「有効」，「やや有効」，「不 変・悪化」の 4 段階に分類した。

3. 虚実の判定

小山地が提案している「証決定のための質問表」 を用いて，患者の虚実を判定した。スコアの合計点 により，実証，中間証，虚証の三つに分類した（表 3 )。

4. Drug challenge test

対象症例の内 7 例では，投与前にDCTを行なっ た。検査手順は，まず患者を仰臥位にして，輸液剤 と静脈カニューラ針にて静脈路を確保する。次ぎに， 試験薬剤を点滴セットの側管より，輸液剤を滴下し ながらゆっくりと投与した。試験薬剤投与 5 分， 10

表 2 各指標の改善度判定基準

\begin{tabular}{|c|c|c|c|c|}
\hline \multirow{2}{*}{ 指 標 } & \multicolumn{2}{|r|}{ 有 } & 効 性 & \multirow[b]{2}{*}{ 不変·悪化 } \\
\hline & 著効 & 有効 & やや有効 & \\
\hline $\begin{array}{l}\text { 疼痛の重症度 } \\
\text { (治療前後比) }\end{array}$ & $0.25 \geqq$ & $0.5 \geqq$ & $0.75 \geqq$ & $0.75<$ \\
\hline $\begin{array}{l}\text { 疼痛の頻度 } \\
\text { (治療前後差) }\end{array}$ & $3 \leqq$ & 2 & 1 & $0 \geqq$ \\
\hline $\begin{array}{l}\text { QOL } \\
\text { (治療前後差) }\end{array}$ & $4 \leqq$ & 3 & 2,1 & $0 \geqq$ \\
\hline
\end{tabular}

表 3 証決定のための質問表

\begin{tabular}{|c|c|c|c|c|}
\hline & はい & 中間 & いいえ & 点数 \\
\hline (1)体質は筋肉質ですか? & 6 & 3 & 0 & \\
\hline (2)固太りの方ですか? & 6 & 3 & 0 & \\
\hline (3)皮膚はつやがありますか？ & 8 & 4 & 0 & \\
\hline (4)おなかは弾力的で緊張感がありますか? & 8 & 4 & 0 & \\
\hline (5)食べ過ぎても平気ですか？ & 6 & 3 & 0 & \\
\hline (6)食事のスピードは速い方ですか？ & 6 & 3 & 0 & \\
\hline (7) 1 日でも便秘すると不快な方ですか？ & 6 & 3 & 0 & \\
\hline 8暑さ寒さには強い方ですか？ & 6 & 3 & 0 & \\
\hline (9)手足の冷えはありませんか？（※） & 6 & 3 & 0 & \\
\hline (10)活動的ですか？ & 6 & 3 & 0 & \\
\hline (11)余り疲れない方ですか？ & 6 & 3 & 0 & \\
\hline (12)声は力強い方ですか？ & 8 & 4 & 0 & \\
\hline 13行動には常に余裕がありますか？ & 8 & 4 & 0 & \\
\hline (14)胃薬は苦い方が飲みやすいですか？ & 6 & 3 & 0 & \\
\hline (15)寝汗はかかないですか？（※） & 8 & 4 & 0 & \\
\hline \multicolumn{4}{|c|}{$\begin{array}{l}\text { ※：(9)は，冷えがなければ「はい」,あれば「いいえ」を選ぶ。 } \\
\text { (15)は，寝汗をかかな計点 } \\
\text { 判定基準 }\end{array}$} & \\
\hline
\end{tabular}


分，20分後に，薬剤投与前の痛みを10として，薬剤 静注後それがどの程度減少, 消失したのかを, VAS を用いて観察した。最初にプラセボ効果をみるため, コントロールとして生理食塩水 $5 \mathrm{ml}$ を用いた。試 験薬剂は，チオペンタール $25 \mathrm{mg}$ とリドカイン $(2 \%)$ $2 \mathrm{ml}$ である。DCT の結果判定は, VAS スコアが 0 〜 2 になった場合を陽性 $(++), 3 〜 6$ になった場 合を陽性 $(+)$ とした。1日につき1薬剤の試験にと どめた。なお，実際の施行にあたっては，検査の意 義および薬剤の副作用と対策などを説明し，患者の 同意を得て行なった。

\section{5 . 統計解析}

Wilcoxon の符号付順位検定, Mann-Whitney の U 検定抢よび $\chi$ 乗検定を用いた。なお， $\mathrm{P} \leqq 0.05$ 統 計的有意差ありとした。

\section{結果}

PTPD の部位は，下腹部12例 $(80 \%)$, 尿道・陰 茎 4 例 (27\%), 陰囊 5 例 (33\%), 会院部 7 例 (47\%) であった。単独の部位は 2 例で, 残りの 13 症例は同 時に他の部位と合併していた。排尿時の疼痛／不快 感は 1 例, 射精時の疼痛は 2 例に認めた。竜胆瀉肝 湯投与前後の疼痛の重症度と頻度スコアおよび QOL スコアの経時的変化は, 表 4 に示した。有効 群は症例 1〜9，11，15の計11例 (73\%), 無効群 は症例10，12～14の計 4 例（27\%）であった。有効 群と無効群の症例の年令 (平均土標準偏差) は, 前

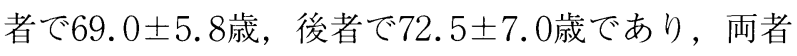
に統計的有意差 $(p=0.1332)$ を認めなかった。有 効群では, 竜胆瀉肝湯服用 2 週間目で, 疼痛の重症 度スコアは11例全例（100\%), 疼痛の頻度スコアは
表 4 竜胆瀉肝湯投与前・後の 3 指標スコアの経時的変化

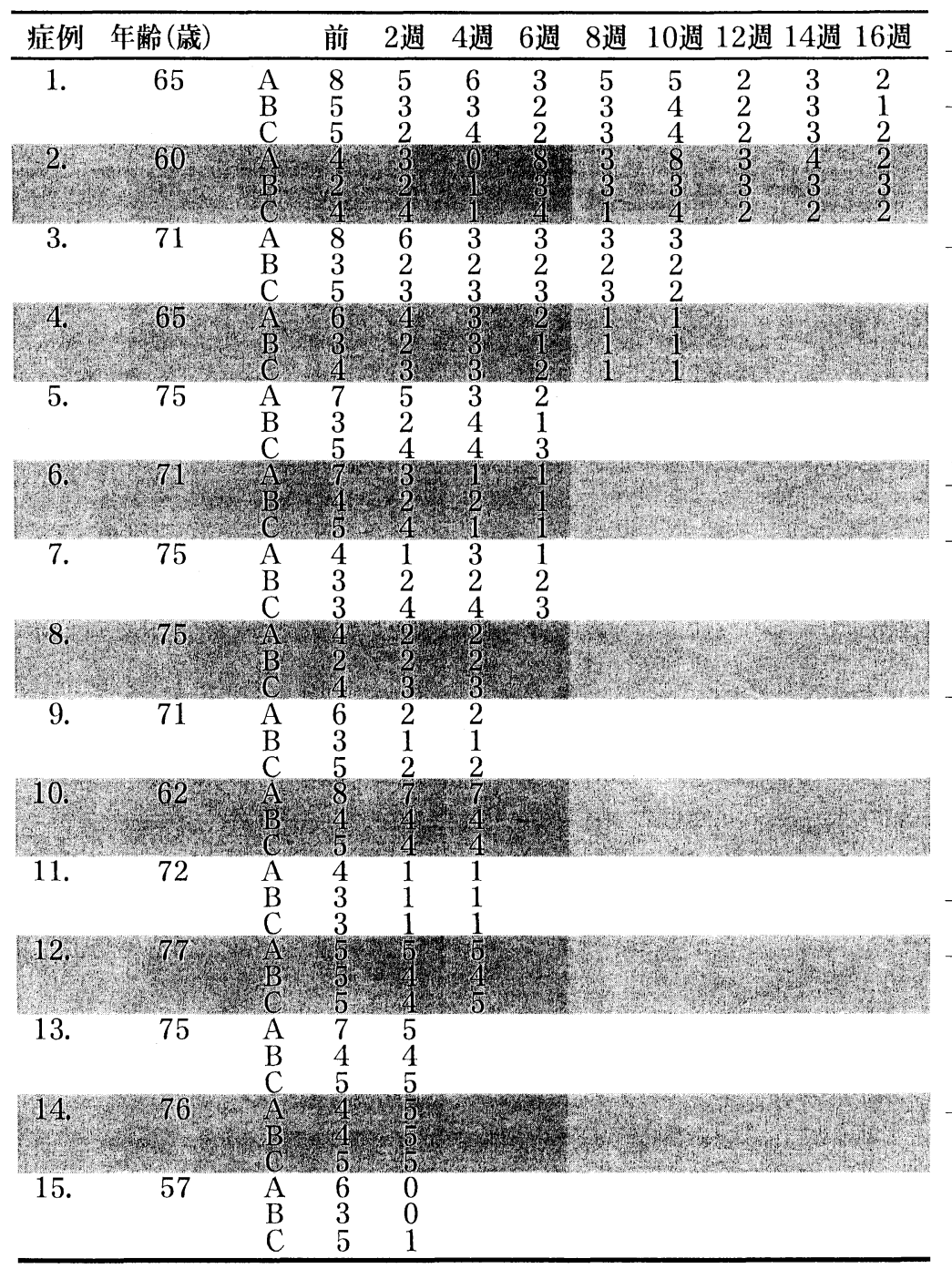

表 5 竜胆瀉肝湯投与前と投与終了時の各 指標の比較

\begin{tabular}{lccc}
\hline \multicolumn{1}{c}{ 指 標 } & 投与前 & 投与終了時 & $\mathrm{p}$ \\
\hline 疼痛の重症度 & $5.8 \pm 1.5$ & $2.6 \pm 1.9$ & 0.0014 \\
疼痛の頻度 & $3.4 \pm 0.9$ & $2.0 \pm 1.5$ & 0.0096 \\
QOL & $4.5 \pm 0.7$ & $2.6 \pm 1.4$ & 0.0033 \\
\hline
\end{tabular}

投与終了時は，2１6(平均5.8)週である。 数字は, 平均士標準偏差を示す。

$\mathrm{p}$ 值は wilcoxon 符号付順位検定による。

表 6 竜胆瀉肝湯投与による各指標の改善度

\begin{tabular}{|c|c|c|c|c|}
\hline 指＼cjkstart標 & 著効 & 有効 & やや有 & 変·悪化 \\
\hline 疼痛の重症度 & 5 & 6 & 1 & 3 \\
\hline 疼痛の頻度 & 3 & 4 & 3 & 5 \\
\hline QOL & 2 & 4 & 5 & 4 \\
\hline
\end{tabular}

数字は, 症例数を示す。

表 7 有効群と無効群の各指標の比較 (竜胆瀉肝湯投与前)

\begin{tabular}{lccc}
\hline \multicolumn{1}{c}{ 指 標 } & 有効群 & 無効群 & $\mathrm{p}$ \\
\hline 疼痛の重症度 & $5.8 \pm 1.6$ & $6.0 \pm 1.8$ & 0.7940 \\
疼痛の頻度 & $3.0 \pm 0.8$ & $4.2 \pm 0.5$ & 0.0265 \\
QOL & $4.3 \pm 0.8$ & $5.0 \pm 0.0$ & 0.1177 \\
\hline
\end{tabular}

数字は, 平均土標準偏差を示す。 $\mathrm{p}$ 值は Mann-Whitney のU 検定による。 
9 例 $(82 \%)$, QOL スコアは 9 例 $(82 \%)$ が減少し た。その後の各スコアの推移は, 一時的な増加を示 す症例（症例 $1 ， 2 ， 4 ， 5 ， 7$ ）があるが，大部 分の症例では経時的な減少を示した。しかし, 疼痛 頻度スコアでは 2 例（症例 2 と 8 ), QOL スコアで は 1 例（症例 7 ）が不変・悪化を示した。一方, 無 効群では竜胆瀉肝湯服用 $2 \sim 4$ 週間後でも, 各指標 スコアは不変・悪化またはわずかの減少しか示さな かった。投与終了時は, 前者では 2 週間が 1 例, 4 週間が 3 例, 6 週間が 3 例, 10 週間が 2 例, 16週間 が 2 例, 後者では 2 週間が 2 例, 4 週間が 2 例であっ た。竜胆䵘肝湯投与終了時の疼痛の重症度スコアと 疼痛の頻度スコア, および QOL スコアは投与前と 比較してそれぞれ統計的に有意の減少が認められた

(表 5 )。3 指標スコアの改善度判定でやや有効以 上の改善を示したのは, 重症度スコアでは12例 (80\%), 頻度スコアでは10例 $(67 \%)$, QOLスコ アでは11例（73\%）であった（表 6$)$ 。この改善度 から治療効果を判定すると，2 ないし 3 つの指標の 改善度がやや有効以上の場合が有効群で，2つの指 標が不変・悪化を示した場合が無効群であった。

有効群と無効群における, 竜胆瀉肝湯投与前の各 指標スコアの比較では, 疼痛の重症度と QOL は両 群で統計学的有意差を認めなかったが, 疼痛の頻度 は有意差を認めた（表 7 ）。虚実判定スコアに基づ く判定では, 実証が 5 例, 中間証が10例で, 虚証の 症例は認められなかった。有効群では, 実証 3 例と 中間証 8 例, 無効群では実証 2 例と中間証 2 例で あった。両群間で, 実証と中間証の割り合いには有 意差を認めなかった $(\mathrm{p}=0.4090)$ 。

DCT では，2 試験薬剤を用いて観察できたのは 5 例であった。残りの 2 例は, 生理食塩水での観察
はできたが，試験薬剤については患者の同意が得ら れず行なうことができなかった。チオペンタール陽 性 4／5例 (80\%)，リドカイン陽性 2／5例 (40\%) であった（表 8$)$ 。コントロールの生理食塩水陽性 が3例（43\%）に認められた。試験薬剤に対する反 応性は症例毎に異なり，一定の傾向は認められな かった。また, DCT の結果と竜胆瀉肝湯の治療効 果との間に，明らかな関係は認められなかった。竜 胆瀉肝湯が無効であつた症例のうち, 症例 1 （チ才 ペンタール陽性, リドカイン陽性) ではメキシレチ ン内服は無効であったが, ペントバルビタールカル シウム錠内服が有効であった。症例 5 (チオペンター ル陽性, リドカイン陰性）ではペントバルビタール カルシウム錠内服がやや有効を示した。

なお，竜胆瀉肝湯服用による胃部不快感を 1 例に 認めた。

\section{考察}

PTPD は稀であり，その原因や病態はまだ不明で ある。そのため, PTPDの確立された治療法はなく, われわれの経験では消炎鎮痛薬はあまり有効ではな い。PTPD と同類と考えられる病態に尿路不定愁訴 がある。これは，検尿，尿培養，前立腺液および尿 路の画像診断などに異常が認められず，排尿痛・不 快感, 残尿感, 頻尿, 会陰部や下腹部などの疼痛・ 不快感などを訴える症例である。PTPD は排尿障害 を伴うことが少ないという点が，尿路不定愁訴との 違いである。この尿路不定愁訴は一般に, 慢性前立 腺炎, 慢性膀胱炎, 神経性頻尿と診断されて, 抗菌 薬，消炎鎮痛薬，抗コリン薬などによる治療が行な われているが, PTPD と同様に必ずしも有効ではな い。しかし，この尿路不定愁訴の治療に，漢方薬が 有効であると報告されている5)。一般に, 清心蓮子

表 8 Drug challenge test $の$ 成績

\begin{tabular}{ccllll}
\hline 症例 & 年齢(歳) & 生理食塩水 & チオペンタール & リドカイン & $\begin{array}{l}\text { 治療効果 } \\
\text { (竜胆瀉肝湯) }\end{array}$ \\
\hline 1 & 75 & 陰性 & 陽性 $(++)$ & 陽性 $(+)$ & 無効群 \\
2 & 76 & 陰性 & 陰性 & 陰性 & 無効群 \\
3 & 71 & 陽性 $(+)$ & 陽性 $(++)$ & 陽性 $(++)$ & 有効群 \\
4 & 59 & 陰性 & 陽性 $(++)$ & 陰性 & 有効群 \\
5 & 62 & 陰性 & 陽性 $(+)$ & 㓌性 & 無効群 \\
6 & 71 & 陽性 $(++)$ & $\mathrm{np}$ & $\mathrm{np}$ & 有効群 \\
7 & 60 & 陽性 $(++)$ & $\mathrm{np}$ & $\mathrm{np}$ & 有効群 \\
\hline
\end{tabular}

$(++): \operatorname{VAS} 0 \sim 2,(+): \operatorname{VAS} 3 \sim 6, \mathrm{np}:$ 未施行 
飲 ${ }^{6)}$, 猪苓湯 ${ }^{7)}$, 猪苓湯合四物湯 ${ }^{8)}$, 八味地黄丸 ${ }^{9)}$ どの漢方薬が使用されている。これらの薬剤の有効 率は，医師の主観的な治療効果判定によるものがほ とんどであるが，33\%から87\%と報告されている。 その中に, TURP術後の尿路不定愁訴に猪苓湯を投 与し, 有効 1 例, やや有効 1 例, 不変 5 例であった という報告がある7゙。しかし，今まで，竜胆瀉肝湯 が PTPDの治療に有効性があるということを検討し た報告はない。

竜胆瀉肝湯は「肝経湿熱，玉茎瘡を患い，或いは 便毒, 下疳, 懸堍の腫脹, 小便赤く渋滞し, 陰囊の 腫脹するを治す」(出典：薛氏十六種）とされてい る。その生薬構成は, 当帰, 地黄, 木通各 $5.0 \mathrm{~g}$, 黄 芩, 沢瀉, 車前子各 $3.0 \mathrm{~g}$, 竜胆, 山梮子, 甘草各 $1.0 \mathrm{~g}$ である。全体に, 瀉, 燥の生薬が多く配剂されてお り，実証の方剤とされている。それぞれの生薬の薬 理作用は，鎮痛・鎮静作用，抗炎症作用，抗菌・免 疫賦活作用，抗アレルギー作用，利尿作用，血行促 進などである。主として, 泌尿·生殖器の炎症性疾 患に使用され，陰部粘膜および周辺皮䖉の糜爛，潰 瘍, 硬結, 膿瘍など, また排尿痛, 排尿後不快感, 頻尿，排尿困難などが使用目標とされる ${ }^{10)}$ 。臨床的 には，子宮腔部糜爛，臸炎，難治性帯下，陰股部の 膿皮症，尿路不定愁訴などに用いて有効であったと

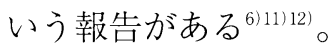

われわれの治療成績では，PTPDに対する竜胆䵘 肝湯の有効率は15例中11例（73\%）であった。疼痛 の重症度と頻度および患者の満足度の各指標スコア は，いずれも竜胆鴪肝湯により有意の改善を示した。 竜胆瀉肝湯の治療効果は, 有効症例では 2 週間とい う比較的短期間でも認められ，その後も経時的に症 状の改善が進行した。最大の効果発現を示す投与終 了迄の期間は $2 \sim 16$ 週（平均7.6週）であった。他 方, 無効症例では, $2 \sim 4$ 週 (平均 3 週) の治療期 間中に症状の改善が認められなかった。従って, 竜 胆瀉肝湯を投与して 4 週間後に症状の改善が認めら れない場合，それ以後は他の治療法に移行すべきと 考える。

竜胆瀉肝湯の有効症例と無効症例における患者の 質の違いを検討してみると, 年令, 疼痛の重症度お よび QOL は両者で有意差を認めなかった。疼痛の 頻度だけは無効症例の方が高いスコアを示したが, その理由は不明である。竜胆鴪肝湯は実証に有効と
されているので, 虚実との関係を見てみると, 我々 の用いた小山の質問表年による判定に基づいた場合, 実証の 5 例中 3 例 $(60 \%)$ および中間証の 10 例中 8 例 $(80 \%)$ が有効症例であった。従って, 竜胆潟肝 湯は実証ばかりでなく, 中間証にも高い効果が認め られた。しかし, 今回は虚証と判定される症例がい なかったので, 虚証と竜胆瀉肝湯の有効性との関係 は観察できなかった。

われわれは, PTPDの発生機序に神経性因子が関 与しているかどうか, DCT を用いて検討した。DCT は, 疼痛を有する患者に疼痛に関与する各種の薬剤 を静脈投与し, 疼痛の消長を観察することにより, その神経因性疼痛の発生機序を推定し, 治療法の選 択にも応用しようという薬理学的な検査法である ${ }^{31}$ 。 試験薬剤のチオペンタールは, 痛覚伝導路における 損傷部よりも, 中枢側で生じたニューロンの過㮃活 動により起きる求心路遮断性疼痛で陽性を示すこと が多い。リドカインは損傷された神経線維や神経細 胞における異所性の異常活動電位の有無を調べるも ので, その除痛効果は, 脊髄の広域作動ニューロン の過剩興奮を抑制するためと言われている゙3。今回 のわれわれの PTPD 患者における DCT の成績では,

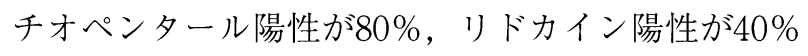
に認められた。しかし，両試験薬の反応が PTPD 患 者毎に異なり，一定の傾向を見い出すことができな かった。さらに, プラセボ効果を示す生理食塩水に も陽性を示す症例も存在した。これらの所見は PTPDの複雑性を示しており, PTPDの発生機序に は, いわゆる慢性疼痛 ${ }^{13}$ の特異的な性質と同様に, 中枢性と末梢性の神経的要素と心因的要素が複雑に 絡み合っていると推定された。

竜胆瀉肝湯の PTPD に対する改善効果の機序は未 だ不明であるが，われわれは竜胆瀉肝湯の鎮痛作用 や鎮静作用などが相互に作用して改善効果をもたら すのではないかと推定している。

我々の成績では, DCT と竜胆㴼肝湯の治療効果 との間には明らかな関係を認めなかった。しかし， 竜胆瀉肝湯無効例の内で, DCT ではチオバルビター ルテスト陽性を示し, ペントバルビタールカルシウ ム錠内服が有効であった症例を認めたことより， DCT は治療法の選択にあたって有用な場合もある と思われる。今回 DCT を行なった症例が比較的少 人数であったこと，また今回用いた試験薬剤以外の 
薬剂 (交感神経遮断薬，ケタミン，モルヒネなど) を用いて DCTを行なった場合, 今回と異なる結果 が得られる可能性もあることを考慮し, 竜胆瀉肝湯 の適応に対する DCT の有用性について今後の検討 が必要であると考える。

以上より, 竜胆瀉肝湯は PTPD の治療の選択肢の 一つとして，有用性があることを認めた。今後は症 例を重ね, 多施設での検討も考慮に入れて研究した いと考えている。

附記 本論文の要旨は第20回泌尿器科漢方研究会学 術集会（2002.4.18，東京）において発表した。

謝辞 稿を終えるに当たり，本論文の御校閲を賜つ た富山医科薬科大学寺澤捷年教授，有益な御助言をい ただいた城東クリニック市堰 徹先生に深甚なる謝意 を表します。

\section{文献}

1 ) Litwin M.S., et al. : The national institutes of health chronic prostatitis symptom index : Development and validation of a new outcome measure. J. Urol., 162, 369-375 (1999)

2 ) Kunishima Y., et al. : National institutes of health chronic prostatitis symptom index for Japanese men.
Urology, 60, 74-77 (2002)

3 ）小川節朗：ドラッグチャレンジテストの意義と方 法，ペインクリニック，17，587-595（1996）

4 ）小山蒿夫：子宮内膜症と漢方，産婦人科治療， 67, 393-396 (1993)

5 ）石橋 晃：病態別和漢薬の選び方, 使い方, 1. 尿 路不定愁訴，臨泌，45，283-286（1991）

6 ）石橋 晃, 他：下部尿路不定愁訴に対する清心蓮 子飲治療，泌尿紀要，30，275-277（1984）

7 ) 宮北英司，他：尿路不定愁訴に対する猪苓湯の効 果，西日泌尿，47，1859-1861（1985）

8 ）堀井明範, 他：尿路不定愁訴に対する猪苓湯, 猪 苓湯合四物湯の効果, 泌尿紀要, 34, 2237-2241 (1988)

9 ) 後藤 甫, 他: 泌尿器科領域における八味地黄丸 の治療，泌尿紀要，26，103-107（1980）

10）松田邦夫：臨床応用「万病回春」竜胆瀉肝湯, 漢 方診療， 11，6-17（1992）

11）木村博子：子宮腔部びらん・帯下に対する竜胆瀉 肝湯の使用経験，漢方診療，7，31-34（1988）

12）松田三千男，他：竜胆瀉肝湯が奏効した陰股部の 慢性膿皮症の 1 例, 日本東洋医学雑誌, 45, 377380 (1994)

13）村上良介：慢性疼痛というもの, 痛みと漢方, 2,1 -7 (1992) 